\title{
NARASI KUASA KONTEN HOMOSEKSUAL DI MEDIA SOSIAL "WATTPAD"
}

\section{Zafirah Quroatun 'Uyun, ${ }^{1}$ Ariza Qurrata A'yun², Wiranda Rasnika ${ }^{3}$}

\author{
${ }^{1}$ Institut Agama Islam Negeri Batusangkar \\ ${ }^{2}$ Universitas Islam Negeri Sunan Ampel Surabaya \\ ${ }^{3}$ Institut Agama Islam Negeri Batusangkar \\ 1'zafirah@iainbatusangkar.ac.id, 2arizaqurrata@uinsby.ac.id, ${ }^{3}$ wirandarasnika119@gmail.com
}

\begin{tabular}{l}
\hline \hline Article Info \\
\hline Article history: \\
Received 15 Juli 2021 \\
Accepted 27 Agustus 2021 \\
Published 1 Oktober 2021 \\
\hline
\end{tabular}

Keyword:

Konten, Homoseksual, Fujoshi, Wattpad

\begin{abstract}
The spread of homosexual content on social media platform Wattpad, there is fujoshi community that already exists in Indonesia. The fujoshi community provides homosexual content and making it legal to enjoy it. The purpose of this study is to find out fujoshi homosexual narrative in Indonesia using Wattpad. This research uses discourse analysis method. The results showed that the homosexual narrative built by fujoshi on Wattpad is unique, using other terms from Japanese (yaoi, uke, seme) and English (Boys Love, BL, and M-Preg) in order to be unrecognized by legal censors. The propagator of this content is the opposite sex of homosexuals, namely women, through imagination and fantasy, which is expressed in the form of images and writings. In addition, texts are produced and distributed based on favorite idol pairs. Although it is not produced every day, fanfiction is produced after receiving feedback in the form of fanservice from their idol couples. After being produced, fanfiction is distributed through Wattpad and notified to consumers (readers) through notifications which can be accessed completely freely.

Penyebaran konten homoseksual di platform media sosial Wattpad, terdapat ada komunitas seperti fujoshi yang telah ada di Indonesia. Komunitas fujoshi memberikan konten-konten homoseksual sekaligus menjadikannya legal dinikmati. Tujuan penelitian ini adalah untuk mengetahui narasi homoseksual fujoshi di Indonesia yang menggunakan Wattpad. Penelitian ini menggunakan metode analisis wacana. Hasil penelitian diperoleh bahwa narasi homoseksual yang dibangun oleh fujoshi pada Wattpad tergolong unik, yakni menggunakan istilah lain dari bahasa Jepang (yaoi, uke, seme) dan Inggris (Boys Love, BL, dan M-Preg) agar tidak dikenali sensor legal. Penyebar konten ini adalah lawan jenis dari homoseksual, yakni para kaum perempuan melalui imajinasi dan fantasi, yang dituangkan dalam bentuk gambar dan tulisan. Selain itu, teks diproduksi dan didistribusikan berdasarkan pasangan idola favorit. Meski tidak diproduksi setiap hari, tetapi fanfiction diproduksi setelah mendapat umpan balik berupa fanservice dari pasangan idola. Setelah diproduksi, fanfiction disebarkan (didistribusikan) melalui Wattpad, dan diberitahukan terhadap konsumen (pembaca) melalui notifikasi yang mana dapat diakses sepenuhnya secara leluasa.
\end{abstract}

Copyright (C) 2021 Jurnal Ilmu Komunikasi. All rights reserved.

Editorial Office:

Program Studi Ilmu Komunikasi, Fakultas Dakwah dan Komunikasi, UIN Sunan Ampel Surabaya. Jl. Ahmad Yani 117 Surabaya, Jawa Timur, Indonesia.

Email: jurnalilkom@uinsby.ac.id 


\section{Pendahuluan}

Isu mengenai penyimpangan saat ini tengah menjadi sorotan publik, salah satunya isu mengenai penyimpangan orientasi seksual. Orientasi Seksual dapat diartikan sebagai kecenderungan seseorang untuk mengarahkan rasa ketertarikan, romantisme, emosional, dan seksualnya untuk wanita, pria, atau kombinasi keduanya. Perilaku tersebut dikenal dengan istilah LGBT (Lesbi, Gay, Biseksual, Transgender).

Istilah LGBT telah digunakan sejak tahun 1990-an, menggantikan frasa 'kelompok gay' yang dianggap atau dinilai mewakili kelompok yang 'mengisi' istilah LGBT. LGBT terdiri atas kelompok: ${ }^{1}$ Pertama, Lesbi: kelompok wanita yang secara fisik, emosional, dan/atau spiritual merasa tertarik dengan wanita lain. Kedua, Gay: kelompok pria yang secara fisik, emosional, dan/atau spiritual merasa tertarik dengan pria lain. Ketiga, Biseksual: kelompok orang yang secara fisik, emosional, dan/atau spiritual merasa tertarik baik kepada lawan jenis dan sesama jenis. Keempat, Transgender: kelompok orang yang merasa identitas gendernya berbeda dengan anatomi

\footnotetext{
${ }^{1}$ Roby Yansyah dan Rahayu, "Globalisasi Lesbian, Gay, Biseksual, dan Transgender (LGBT): Perspektif HAM dan Agama Dalam Lingkup Hukum Di Indonesia," Jurnal Law Reform 14, no.1 (March 2018): 133, DOI: https://doi.org/10.14710//r.v14i1.20242

${ }^{2}$ Meilanny Budiarti Santoso, "LGBT Dalam Perspektif Hak Asasi Manusia," SHARE: Social
}

kelamin yang dimiliki, sehingga memilih/tidak memilih untuk melakukan operasi kelamin menyesuaikan dengan identitas gender yang diinginkan.

Di Indonesia, LGBT bukanlah hal baru. Menurut survey ${ }^{2}$ CIA pada tahun 2015 jumlah populasi LGBT di Indonesia adalah ke-5 terbesar di dunia setelah China, India, Eropa dan Amerika. Selain itu, beberapa lembaga survey independen dalam maupun luar negeri menyebutkan bahwa Indonesia memiliki 3\% penduduk LGBT, ini berarti dari 250 juta penduduk 7,5 jutanya adalah LBGT, atau lebih sederhananya dari 100 orang yang berkumpul di suatu tempat 3 diantaranya adalah pelaku LGBT.

Sedangkan dalam jurnal ilmiah ${ }^{3}$ menyebutkan jumlah kelompok LGBT di Banda Aceh sudah mencapai 530 orang yang mayoritasnya merupakan mahasiswa, 70\% didominasi oleh kaum gay dan selebihnya dari berbagai kaum seperti lesbian, biseksual dan transgender. Komunitas ini semakin gencar berkampanye untuk menunjukkan eksistensi ke publik. Angka itu diperkirakan akan jauh lebih banyak lagi. Jumlah angka anggota LGBT yang ditemukan oleh kantor PPKB Kota Banda Aceh diperoleh dari survei media sosial. Work Jurnal 6, no. 2 (Desember 2016): 221, DOI
: https://doi.org/10.24198/share.v6i2.13206
3 Dana Dwi Prasetyo dan Amsal Amri, "Peranan
UP3AI Unsyiah mengantisipasi pengaruh
pemberitaan LGBT di media online terhadap
mahasiswa," Jurnal Ilmiah Mahasiswa FISIP
Unsyiah 2, no. 3 (Agustus 2017): 3,
http://www.jim.unsyiah.ac.id/FISIP/article/view/36
68

Editorial Office:

Program Studi Ilmu Komunikasi, Fakultas Dakwah dan Komunikasi, UIN Sunan Ampel Surabaya.

Jl. Ahmad Yani 117 Surabaya, Jawa Timur, Indonesia.

Email: jurnalilkom@uinsby.ac.id 
Terdapat salah satu kelompok dalam LGBT yang memiliki pengikut yang namanya sering terdengar, yakninya kelompok gay (homoseksual). Hal ini karena mudahnya penggunaan internet oleh gay untuk mengakses chat, room, social networks, dan tempat lainnya di internet untuk bersosialisasi, alat mencari informasi, keinginan untuk membentuk jaringan dan pertemanan, sebagai cara untuk menjaga kerahasiaan, dan menjadi tempat aman sebelum bertemu, serta untuk mencari pengalaman, hiburan, dan pelarian. Jejaring sosial yang ditujukan untuk kaum homoseksual adalah hal yang mungkin tidak banyak diketahui oleh masyarakat khususnya bagi mereka yang menolak kehadiran gay (homoseksual). Gindr, Badoo, Jack'd, Tagged, dan Scruff merupakan jejaring sosial yang membuat kelompok homoseksual bebas berkomunikasi dengan sesamanya. ${ }^{4}$ Penggunaan media sosial oleh kelompok homoseksual dikarenakan adanya kebebasan mengatur diri dan mengembangkan kepribadian tanpa adanya proses tatap muka, serta kecepatan dalam menyampaikan informasi, interaksi lebih mudah dilakukan. Sehingga mereka dapat membuka diri terhadap sesamanya.

Kelompok gay (homoseksual) memiliki penggemar tersendiri yang sering dikenal dengan istilah Jepang, yaitu fujoshi dan fudashi, hanya saja yang sering terdengar ialah fujoshi. Fujoshi merupakan sebutan yang digunakan masyarakat

\footnotetext{
${ }^{4}$ Dwinita Mardiani, "Pemaknaan Media Sosial Bagi Kaum Homoseksual: Studi Fenomenologi pada Pengguna Grindr," Skripsi, (Fakultas Ilmu Komunikasi Universitas Multimedia Nusantara Tangerang Banten: 2017): 4.

5 Yueni Andri Ani, "Fujoshi Ala Indonesia Dalam Penciptaan Komik,” Invensi 3, no. 1 (Juni 2018):
}

Jepang untuk menyebut para wanita maupun gadis yang menyukai komik maupun novel yang berunsur yaoi (bacaan atau tontonan yang menampilkan hubungan romantis antara lelaki). ${ }^{5}$ Generasi milenial sering menyebutnya dengan bromance/boyslove/BL. Fenomena fujoshi pertama kali dikenal sekitar tahun 1970-an di Jepang saat komik yaoi pertama kali diproduksi.

Jika dilihat berdasarkan tabel di atas, Indonesia yang mayoritas penduduknya memeluk agama Islam ${ }^{6}$ tidak dapat terhindar dari fenomena ini. Dalam perkiraan, keberadaan fujoshi di Indonesia mulai terlihat sekitar tahun 2008, sebagai akibat munculnya internet dan maraknya media sosial pada masa itu. Fujoshi di Indonesia rata-rata adalah remaja dan wanita berusia 18 sampai 30 tahun (ada juga yang lebih muda). Kebanyakan diantara mereka berprofesi sebagai pelajar, mahasiswi dan pekerja. Aktif dalam media sosial dan mayoritas memiliki pengalaman bergabung dengan komunitas, seperti Otaku, K-Pop, Wota dan lainnya.

Fujoshi mudah berkembang di Indonesia karena metode penyebarannya yang begitu mudah. Fujoshi mengaku menyukai bacaan $B L$ karena tidak sengaja menemukan sebuah ilustrasi atau kalimat yaoi dari suatu situs, karena penasaran mereka mulai mencari tahu. Dalam sebuah artikel yang mengangkat isu mengenai perempuan dalam masyarakat Jepang

23, file:///C:/Users/User/Downloads/2104-3664-1SM.pdf

6 Badan Pusat Statistik, "Penduduk Menurut Wilayah dan Agama Yang Dianut," diakses 19 Agustus, 2020. https://sp2010.bps.go.id/index.php/site/tabel?tid=3 21 
terbagi dua kategori ${ }^{7}$, yakni sebagai istri yang melahirkan keturunan dan perempuan komoditas industri seks. Stigma ini membentuk resistensi mereka menjadi penggemar komik yaoi/BL. Bisa jadi keberadaan fujoshi di Indonesia juga karena hal tersebut. ${ }^{8}$ Hal ini juga pernah terjadi pada salah seorang teman peneliti. Awal mula ia mengetahui tentang yaoi/homoseksual, karena bergabung dalam suatu komunitas penggemar Korean Pop (K-Pop). Kemudian ia semakin memahami tentang homoseksual setelah membaca fanfiction bertema homoseksual/boyslove/BL. Sehingga, terjadi perubahan pandangan terhadap kelompok homoseksual. Ia tidak lagi menolak kelompok tersebut tetapi juga tidak mendukungnya.

Berdasarkan uraian masalah di atas, maka peneliti bermaksud meneliti Penyebaran Konten Homoseksual di salah satu media sosial yang tanpa disadari ikut mengkampanyekan program-program LGBT. Hal ini menjadi sebuah permasalahan bagi peneliti khususnya, manakala fenomena ini tumbuh menjamur secara perlahan tapi pasti bahkan sulit terdeteksi karena menggunakan simbolsimbol komunikasi tersendiri yang tersebar melalui media sosial dan mengancam keutuhan generasi. Dalam kaitannya dengan relasi, kuasa (power) berperan penting dalam penyebaran teks-tels homoseksual. Kebijaka mengenai legalitas konten, mana yang layak atau tidak

\footnotetext{
${ }^{7}$ Mark J. McLelland, "The Love Between 'Beautiful Boys' in Japanese Women's Comic," Journal of Gender Studies 9, no. 1 (August 2010): 14, https://doi.org/10.1080/095892300102425

${ }^{8}$ Ani, "Fujoshi Ala," 25-28.
}

dikonsumsi, menjadi sepenuhnya tanggung jawab individu masing-masing. Tentu hal ini menyalahi teori media social dimana produsen dan consumen pesan tetap dibawah regulasi negara, bukan hanya penyedia jasa. Konsekuensi logisnya, Industri budaya dan teks media di bawah narasi kuasa segelintir orang, bukan lagi bebas dan layak tersebar sesuai fungsi media to inform, to educate, bahkan narasi yang terbentuk menjadi legal.

Padahal dalam pandangan syariat Islam, perilaku homoseksual seperti yang dilakukan oleh kaum Nabi Luth as merupakan dosa besar yang dilaknat oleh Allah swt., Zina dan perbuatan seks menyimpang lainnya seperti homoseksual dipandang bertentangan dengan martabat dan naluri manusia yang beradap. Menurut Hamka Haq yang merujuk pada surat AlA'raf ayat 81 inilah sebagai penyebab mengapa Allah mengharamkan homoseksual. ${ }^{9} \quad$ Sebagaimana yang dijelaskan dalam Q.S Al-A'raf ayat 81 yang artinya "Sungguh, kamu telah melampiaskan syahwatmu kepada sesama lelaki bukan kepada perempuan. Кати benar-benar kaum yang melampaui batas." (Q.S Al-A'raf: 81).

Ayat lain dalam Alquran yang menerangkan mengenai larangan terhadap hubungan seksual sesama jenis (homoseksual) dan mensifatinya sebagai perbuatan fahishah (amat keji), berlebihlebihan, dan melampaui batasm

\footnotetext{
9 Nicky Franida Nugrahani, "Bahaya Komunitas Homoseksual Di Media Sosial (Studi Kasus: Interaksi Virtual Community Media Sosial Gindr)," Skripsi, (Fakultas Ilmu Dakwah dan Ilmu Komunikasi Universitas Islam Negeri Syarif Hidayatullah: 2016): 5.
} 
sebagaimana dijelaskan dalam al-Qur'an, yang artinya

"Mengapa kamu mendatangi jenis lelaki di antara manusia. Dan kamu tinggalkan isteri-isteri yang dijadikan oleh Tuhanmu untukmu, bahkan kamu adalah orang-orang yang melampaui batas" (Q.S Asyu'ara: 165-166).

"Dan (ingatlah kisah) Luth, ketika Dia berkata kepada kaumnya: "Mengapa kamu mengerjakan perbuatan fahisyahperbuatan keji itu sedang

kamu memperlihatkan(nya)?". Mengapa kamu mendatangi laki-laki untuk (memenuhi) nafsu (mu), bukan (mendatangi) wanita? sebenarnya kamu adalah kaum yang tidak mengetahui (akibat perbuatanmu)". (Q.S An-Naml: 54-55)

Perbuatan keji: menurut jumhur mufassirin yang dimaksud perbuatan keji ialah perbuatan zina, sedang menurut Pendapat yang lain ialah segala perbuatan mesum seperti : zina, homo sek dan yang sejenisnya. menurut Pendapat Muslim dan Mujahid yang dimaksud dengan perbuatan keji ialah musahaqah (homoseks antara wanita dengan wanita).

\section{Media Sosial dan Legalitas Konten}

Konten (dalam bahasa inggris: content) adalah informasi yang tersedia melalui media atau produk elektronik. Sedangkan konten media merupakan berbagai bentuk konten atau isi dalam sebuah media di dunia teknologi yang ada pada saat ini seperti blog, wiki, forum, gambar digital, video, file audio, iklan

10 Husnun Azizah, "Konten Kreatif Youtube Sebagai Sumberpenghasilan Ditinjau Dari Etika Bisnis Islam (Studi Kasus Youtuber Kota Metro),' hingga berbagai bentuk konten media lainnya yang terbentuk melalui buatan dari para pengguna sistem atau layanan online yang seringkali dilakukan lewat sebuah situs media online. ${ }^{10}$ Maka, istilah konten digunakan untuk menjelaskan beragam bentuk isi dari informasi dalam suatu media.

Terdapat beragam jenis atau bentuk isi dari informasi dalam suatu konten. Saat ini, marak dibuat melalui media online dengan berbagai bentuk. Berikut ini beberapa jenis dari konten yang ada: (1) Teks: berupa tulisan yang berisi berbagai ulasan, kajian, analisis, deskripsi, pengertian; (2) Gambar; (3) Infografis: representasi visual informasi, data atau ilmu pengetahuan secara grafis. Grafik dapat memperlihatkan informasi rumit dengan singkat dan jelas. Seperti pada papan, peta, jurnalisme, penulisan teknis, dan pendidikan; (4) Meme: gambar lucu berisi sindiran atau kritik; (5) Video: cenderung berdurasi beberapa menit, dapat berisi penjelasan singkat tentang apapun. Dapat berdasarkan humor atau pembelajaran; (6) Podcast: konten dalam bentuk audio, isinya orang bercerita mirip dengan radio namun lebih luas; (7) Tautan (Link): cara yang dapat diakses bagi pembaca untuk menjangkau situs/blog lain yang disukai atau direkomendasikan; (8) Game: game termasuk jenis konten, karena dapat berisi cerita dan merupakan bagian dari konten hiburan; (9) Quick Response Code ( $Q R$ Code): adalah barcode dua dimensi yang dapat menyimpan data. Dapat dipindai pada ponsel untuk

Skripsi, (Fakultas Ekonomi dan Bisnis Islam IAIN Metro: 2020): 11. 
memunculkan penawaran atau tautan ke produk/situs web.

Homoseksual adalah konsep untuk menjelaskan seseorang yang memiliki ketertarikan secara perasaan ataupun erotik baik secara predomian ataupun ekslusif terhadap individu yang memiliki kesamaan jenis kelamin dengan ataupun tanpa melibatkan hubungan fisik. Memurut Olson ${ }^{11}$, Homoseksualitas adalah kesenangan yang terus menerus terjadi dengan pengalaman erotis yang melibatkan kawan sesama jenis, yang dapat atau mungkin saja tidak dapat dilakukan dengan orang lain atau dengan kata lain, homoseksualitas membuat perencanaan yang disengaja untuk memuaskan diri dan terlibat dalam fantasi atau perilaku seksual dengan sesama jenis.

Maka, dapat disimpulkan Homoseksual merupakan suatu aktivitas seksual yang menjelaskan seseorang yang memiliki kesenangan terus menerus, baik secara perasaan atau erotik, predominan (menonjol) maupun ekslusif terhadap sesama jenis dengan atau tanpa melibatkan hubungan fisik.

Menurut beberapa kalangan setidaknya terdapat empat teori mengenai lahir dan adanya cinta sejenis, yaitu: ${ }^{12}$

1. Perspektif Biologis atau Fisiologis

Tiga hal yang mempengaruhi homoseksual, yaitu gen, hormon, kromosom atau adanya ketidakseimbangan jumlah hormon sejak lahir. Banyak ahli mengatakan homoseksual lahir karena beberapa

\footnotetext{
${ }^{11}$ Rizka Ramadhani Putri, "Penerimaan Gay Dalam Keluarga (Studi tentang Penerimaan Keluarga terhadap Anggota Keluarga yang Gay)," Skripsi, (Fakultas Ilmu Sosial dan Ilmu Politik Universitas Airlangga: 2014): 2 \&10
}

jenis ketidakseimbangan dari hormon yang berhubungan dengan seks. Testosteron merupakan faktor yang menentukan bagi perkembangan karakteristik seks yang sekunder, seperti perubahan suara, dan sebagainya. Sedangkan estrogen merupakan faktor penting dalam pembentukan fisik bagi perempuan.

Penelitian Kolodny dengan menentukan kadar testosteron dan sperma, menemukan para homoseksual ekslusif atau yang mendekati memiliki kadar testosteron yang lebih rendah dari heteroseksual. Laki-laki yang menjadi gay karena biologis biasanya tidak dapat kembali menjadi laki-laki dalam arti sebenarnya, tetapi frekuensinya dapat berkurang. Berbagai penemuan dan penelitian yang dilakukan para ahli membuktikan bahwa faktor biologis memiliki pengaruh terhadap perkembangan homoseks.

2. Perspektif Psikologi

Pada awal perkembangan seksual, dimensi psikologis patut dipertimbangkan dalam melacak penyebab homoseksual. Menurut psikoanalisis Freud, homoseksual bermula dari perkembangan psikoseksual anak saat kecil. Pengalaman hubungan orang tua dan anak sangat berpengaruh terhadap kecenderungan homoseksual. Perspektif perilaku (Teori Perilaku atau Psikoseksual) bahwa homoseksual

\footnotetext{
12 Gesti Lestari, "Fenomena Homoseksual Di Kota Yogyakarta," Skripsi, (Fakultas Ilmu Sosial Universitas Negeri Yogyakarta: 2012): 11-14.
} 
secara mendasar merupakan fenomena proses belajar. Penyebabnya adalah adanya penghargaan atau hukuman atas perilaku seksual sejak awal perkembangan yang cenderung mengarah pada gangguan perkembangan psikoseksual.

3. Perspektif Sosikultural dan Lingkungan

Faktor seseorang menjadi homoseksual dikarenakan keadaan sekitar. Seperti adat istiadat setempat yang telah menjadi tradisi (tampak pada masyarakat adat kepulauan). Situasi lingkungan merupakan salah satu faktor seseorang menjadi homoseksual. Ini tampak pada orang yang telah terisolasi dengan rekan sejenis dalam waktu cukup lama dan ikatan ruang yang ketat seperti penjara dan pesantren.

Sementara itu, Pengaturan alat bukti elektronik tidak terdapat dalam KUHAP, melainkan hanya diatur dalam undangundang tertentu (UU ITE). Mengenai alat bukti elektronik, ada pihak yang mempertanyakan statusnya ketika digunakan untuk membuktikan kejahatan umum di pengadilan. ${ }^{13}$ Kehadiran UU ITE juga belum mampu menangani kasus cyber crime, mengingat fokusnya hanya pada pencemaran nama baik. Apalagi konten yang diproduksi di dunia maya sebagian besar adalah konten ilegal yang menambah panjang daftar kejahatan dunia maya di dunia maya.

Undang-Undang Nomor 11 Tahun 2008 tentang Informasi dan Transaksi

${ }^{13}$ Ramiyanto, "Bukti Elektronik Sebagai Alat Bukti Yang Sah dalam Hukum Acara Pidana," Jurnal Hukum dan Peradilan 6, no. 3 (November 2017):
Elektronik (UU ITE) adalah undangundang pertama di bidang Teknologi Informasi dan Transaksi Elektronik sebagai produk legislasi yang sangat dibutuhkan dan telah menjadi pionir yang meletakkan dasar pengaturan di bidang pemanfaatan Teknologi Informasi dan Transaksi Elektronik. Akan tetapi, dalam kenyataannya, perjalanan implementasi dari UU ITE mengalami persoalanpersoalan. Kemudian Undang-Undang Nomor 19 Tahun 2016 UU ITE membahas tentang perubahan Undang-Undang Nomor 11 Tahun 2008 tentang Informasi dan Transaksi Elektronik (UU ITE) pada beberapa pasal.

Pasal-pasal yang mengatur soal penyalahgunaan penyebaran informasi, yaitu pasal 27 ayat (3) Undang- Undang Informasi dan Transaksi Elektronik (UU ITE) Nomor 11 Tahun 2008 yang berhubungan dengan penghinaan/pencemaran nama baik, berbunyi: Setiap orang dengan sengaja dan tanpa hak mendistribusikan dan/atau mentransmisikan dan/atau membuat dapat diakses informasi elektronik dan/atau dokumen elektronik yang memiliki muatan penghinaan dan/atau pencemaran nama baik. yang dimaksud dengan "membuat dapat diakses" adalah semua perbuatan lain selain mendistribusikan dan mentransmisikan melalui Sistem Elektronik yang menyebabkan Informasi Elektronik dan/atau Dokumen Elektronik dapat diketahui pihak lain atau publik. Dan pasal 27 ayat (3) yang berbunyi : Ketentuan pada ayat ini mengacu pada ketentuan

465,

DOI: http://dx.doi.org/10.25216/jhp.6.3.2017.463484 
pencemaran nama baik dan/atau fitnah yang diatur dalam Kitab Undang-Undang Hukum Pidana (KUHP).

Kemudian pasal lain yang berhubungan dengan penyalahgunaan penyebaran informasi elektronik adalah pasal $28 \mathrm{UU}$ ITE Nomor 11 Tahun 2008 ayat (1) yang berhubungan dengan penyebaran informasi berita bohong dan ayat (2) yang berhubungan dengan penyebaran infromasi yang sengaja dan tanpa hak yang menimbulkan rasa kebencian atau permusuhan individu dan/atau kelompok masyarakat tertentu berdasarkan suku, agama, ras, dan antargolongan (SARA). Ketentuan pasal 28 ayat (1) yang berbunyi : Setiap orang dengan sengaja dan tanpa hak menyebarkan berita bohong dan menyesatkan yang mengakibatkan kerugian konsumen dalam Transaksi Elektronik. Kemudian ketentuan pasal 28 ayat (2) yang berbunyi : Setiap orang dengan sengaja dan tanpa hak menyebarkan informasi yang ditujukan untuk menimbulkan rasa kebencian atau permusuhan individu dan/atau kelompok masyarakat tertentu berdasarkan atas suku, agama, ras, dan antargolongan (SARA).

\section{Metode Penelitian}

Penelitian ini menggunakan metode kualitatif analisis wacana mengingat kepentingan penelitian yaitu perlunya mendalami objek penelitian yang berupa studi kasus, teks-teks media yang diproduksi, didistribusi dan dikonsumsi dengan unik, serta analisis hasil wawancara mendalam dengan informan. Objek dalam penelitian yang dilakukan oleh peneliti ialah fujoshi di Indonesia yang menggunakan Wattpad, baik sebagai pembaca, penulis, maupun penulis dan pembaca. Pendekatan yang diambil dalam riset ini adalah pendekatan kritis, media diasumsikan sebagai etintas kepentingan yang penuh dengan prasangka, retorika dan propaganda. Paradigma yang bersumber dari Frankfurt ini mempertanyakan adanya kekuatan-kekuatan yang berbeda dalam masyarakat yang mengontrol proses komunikasi.

Menurut Egon G. Guba dan Lincoln, tujuan dari pendekatan kritis adalah mengkritik transformasi hubungan sosial yang timpang. Peneliti menggunakan pendekatan kritis untuk menemukan konten homoseksual yang diproduksi dan relasi kuasa seperti apa yang menyertai. Penelitian dari tipe kritis pertama kali melihat realitas dan hubungan sosial berlangsung dalam suasana timpang. Media bukanlah saluran yang bebas tempat, semua kekuatan sosial saling berinteraksi dan berhubungan. Sebaliknya, media hanya dimiliki oleh kelompok dominan, sehingga mereka lebih berkesempatan melakukan konstruksi peristiwa berdasarkan sudut pandang dan kepentingan mereka. Media bahkan menjadi sarana dimana kelompok dominan bukan hanya mengukuhkan dominasinya tetapi juga memarjinalkan dan meminggirkan posisi kelompok yang tidak dominan.

\section{Hasil dan Pembahasan}

\section{Narasi Kuasa dalam Perspektif Media}

Kekuasaan (power) dalam kajian media merujuk pada fenomena saat ini adalah decenter the media dimana sistem komunikasi dipandang secara integral terhadap proses ekonomi, politik, sosial, dan budaya yang mendasar di masyarakat. 
Pandangan ini menempatkan media dalam kerangka produksi dan reproduksi yang dibentuk unsur-unsur akumulasi modal, tenaga kerja, dan lain-lain. Media sama dengan dimensi ekonomi, politik, sosial dan budaya, pendidikan keluarga, agama, dan aktivitas kelembagaan. Kesemua aktivitas kelembagaan tersebut dibentuk dalam kapitalisme. Singkatnya bahwa pendekatan ekonomi politik di bidang komunikasi menempatkan subjek komunikasi (media) dalam totalitas sosial yang luas dan karenanya ada kecenderungan untuk mempertimbangkan secara khusus mengenai esensialisme dalam riset komunikasi. Orientasi pendekatan ekonomi-politik bukanlah semata-mata persoalan ekonomi semata, akan tetapi juga pada relasi antara dimensidimensi ekonomi, politik, teknologi, dan budaya dari realitas sosial. Struktur ekonomi politik menghubungkan budaya pada konteks ekonomi dan politiknya dan membuka kajian budaya pada sejarah dan politik. Perspektif ini menganalisa secara penuh campur tangan public sebagai proses legitimasi melalui ketidaksepakatan publik atas bentuk-bentuk yang harus diambil karena adanya usaha kaum kapitalis mempersempit ruang diskursus public dan representasi. Dalam konteks ini dapat juga disebut adanya distorsi dan ketidakseimbangan antara masyarakat, pasar global dan sistem yang ada. ${ }^{14}$

Pada penelitian ini, perangkat analisis yang digunakan adalah analisis wacana kritis milik Norman Fairclough. Fairclough berusaha membangun suatu

${ }^{14}$ Zafirah Quroatun Uyun, "Representasi Identitas Online-Offline dan Budaya Siber di Lingkungan Akademik," Serambi Akademica 8, no. 1 (Februari model wacana yang memiliki kontribusi dalam analisis sosial dan budaya, sehingga tradisi analisis tekstual yang selalu melihat bahasa dalam ruang tertutup dikolaborasikan dengan konteks masyarakat yang lebih luas. Titik perhatian besar dari Fairclough adalah melihat bahasa sebagai praktek kekuasaan. Oleh karena itu, analisis wacana kritis Fairclough memusatkan pada bagaimana bahasa itu terbentuk dan dibentuk dari relasi sosial dan konteks sosial tertentu.

Analisis wacana kritis (CDA) melihat wacana sebagai bentuk praktek sosial. Menggambarkan wacana sebagai praktek sosial menyebabkan adanya sebuah hubungan dialektis di antara peristiwa diskursif tertentu dengan situasi, institusi, dan struktur sosial yang membentuknya. Fairclough melihat bagaimana penempatan dan fungsi bahasa dalam hubungan sosial khususnya dalam kekuatan dominan dan ideologi. Ia berpendapat bahwa analisis wacana kritis adalah bagaimana bahasa menyebabkan kelompok sosial yang ada bertarung dan mengajukan ideologinya masing-masing.

Konsep ini mengasumsikan dengan melihat praktik wacana bisa jadi menampilkan efek sebuah kepercayaan (ideologis). Artinya wacana dapat memproduksi hubungan kekuasaan yang tidak imbang antara kelas sosial, laki-laki dan wanita, kelompok mayoritas dan minoritas di mana perbedaan itu direpresentasikan dalam praktik sosial. Bagi Fairclough, suatu teks yang diproduksi dan dikonsumsi tidak terlepas

2020): 65 DOI: https://doi.org/10.32672/jsa.v8i1.1835 
dari faktor praktek-praktek wacana (discourse practice) yang menjadi mediasi antara teks itu sendiri dengan praktek sosiokultural (sociocultural practice). Pendekatan Fairclough intinya menyatakan bahwa wacana merupakan bentuk penting dari praktek sosial yang mereproduksi dan mengubah pengetahuan, identitas, dan hubungan sosial yang mencakup hubungan kekuasaan dan sekaligus dibentuk oleh struktur dan praktek sosial yang lain. Oleh karena itu, wacana memiliki hubungan dialektik dengan dimensi-dimensi sosial lainnya.

\section{Konten Homoseksual di Watpadd}

Wattpad adalah layanan situs web dan aplikasi ponsel pintar asal Toronto, Kanada. Aplikasi yang diluncurkan pada tahun 2006 oleh Allen Lau dan Ivan Yuen memungkinkan penggunanya untuk membaca ataupun mengirim karya dalam bentuk artikel, cerpen, novel, puisi atau sejenisnya. Penggunaannya sebagian besar berasal dari Amerika Serikat, Britania Raya, Kanada, Filipina, Australia, Rusia, Uni Emirat Arab, dan negara lainnya. ${ }^{15}$ Wattpad memiliki fitu-fitur yang menunjang penggunanya, seperti: halaman utama yang berisi rekomendasi dari berbagai cerita yang ada di Wattpad, mulai dari penulis yang diikuti, berdasarkan tagar yang sering dicari pengguna, dan cerita serupa yang pengguna cari. Selain itu pada halaman utama juga terdapat ikon pengaturan akun pribadi dan pengaturan blokir konten. Fitur lain yang ditawarkan

\footnotetext{
15 Wikipedia, "Wattpad Layanan Situs Web dan Aplikasi Android," diakses 18 Mei, 2019, https://id.m.wikipedia.org/wiki/Wattpad

16 Izmi Wardah Ammar, "Eksistensi Fujoshi Di Kalangan Penciptaan Kebudayaan Jepang (Studi
}

oleh Wattpad adalah halaman pencarian, perpustakaan, editing cerita, dan notifikasi (pemberitahuan).

Fujoshi mudah berkembang di Indonesia karena metode penyebaran yang mudah. Perkembangan fujoshi dimulai secara bertahap. Fujoshi newbie adalah mereka yang baru mencoba dan memiliki rasa ingin tahu yang tinggi. Para pemula ini ada yang ragu-ragu kemudian memilih berhenti atau ada yang penasaran. Mereka yang penasaran inilah yang menjadi fujoshi aktif yang biasanya telah membaca semua rating dan memiliki keterkaitan terhadap rating tertentu. Mereka adalah pemilih yang selalu menunggu update baru. Beberapa yang telah berpengalaman akan mulai membuat karya (doujinshi maupun fanfiction) sendiri yang diunggah melalui situs di internet untuk dibagikan ke sesama fujoshi. Dari karya tersebut ide akan sosok ideal serta perasaan sepaham membuat benak wanita normal menerima pemikiran tersebut dan mulai menjadi fujoshi.

Terdapat beberapa faktor yang membuat fujoshi menyukai yaoi maupun $B L{ }^{16}$ Seperti faktor internal, yakni faktor yang berasal dari dalam diri fujoshi yang mendorongnya untuk menyukai genre yang tidak biasa ini. Beberapa dari faktor internal tersebut diantaranya: penasaran, bosan dengan genre romance yang monoton, tidak suka dengan karakter wanita yang lembek

Selain faktor internal, Ammar juga menjelaskan faktor eksternal para fujoshi menyukai genre yaoi, yakninya: Media

Etnografi Terhadap Wanita Penyuka Fiksi Homoseksual Di Kota Medan," Skripsi, (Fakultas Ilmu Sosial dan Ilmu Politik Universitas Sumatera Utara: 2018): 96-100. 
asupan yang beragam, seperti doujin (karya fans amatir yang meminjam karakter dari suatu serial dan termasuk produk suatu fandom, anime (kata dalam bahasa jepang untuk menyebut animasi buatan tangan atau komputer), dan manga (digunakan untuk menunjukkan komik dan cerita bergambar lainnya.). Selain itu juga adanya forum internasional yang memudahkan fujoshi mendapatkan 'asupan', seperti Aarinfantasy, yakni forum penggemar berbahasa Inggris yang didirikan pada November 2000 oleh Aarin, dan YaoiOtaku. Faktor Ekaternal lainnya seperti banyaknya pilihan cerita yang dibuat dan yaoi tidak menjadikan wanita sebagai objek seksual. ${ }^{17}$

Sebelum masuk ke dalam pembahasan, terlebih dahulu peneliti akan membahas mengenai cara untuk mengetahui apakah akun yang terdapat dalam Wattpad merupakan akun milik fujoshi. Cara untuk mengetahui akun tersebut milik fujoshi atau bukan dapat dilihat dari dua hal. Pertama, profil dan background akun pengguna. Ini dapat dilihat dari gambar yang fujoshi gunakan sebagai simbol. Gambar yang peneliti maksud tentu bukanlah photo asli dari pemilik akun melainkan gambar idola. Biasanya photo yang digunakan adalah photo dua orang laki-laki yang merupakan idola dari si pemilik akun. Ini dilakukan oleh para pemilik akun yang dalam hal ini adalah fujoshi untuk memberitahukan kepada 'orang yang berkunjung' ke akun tersebut bahwa mereka telah memasuki suatu area.

Selain menggunakan gambar berupa photo idola manusia, beberapa fujoshi juga ada yang menggunakan photo dari tokoh kartun, seperti: Sasuke dan Naruto. Ini dilakukan oleh para pemilik akun untuk menandakan suatu area dari idola yang dijadikan tokoh dalam fanfiction. Penggunaan photo tersebut sebagai bentuk tersirat dari para fujoshi untuk mengungkapkan jatidiri mereka yang seorang fujoshi.

Kedua, bio pengguna Wattpad (Wattpeders). Pada bio akun pengguna juga ditemukan simbol berupa teks yang menandakan bahwa akun tersebut adalah milik fujoshi. Simbol berupa teks tersebut biasanya lebih gamblang dibandingkan dengan foto, karena pada bio pengguna akan menuliskan secara langsung bahwa mereka adalah fujoshi, siapa idola yang mereka dukung serta kata-kata berunsur homoseksual.

Pemilik akun juga memberitahu bahwa tema dari fanfiction yang dibuat adalah homoseksual. Ini dapat dilihat dari kata Yaoi, boyxboy. Penggunaan simbol, baik itu melalui gambar ataupun teks, oleh para fujoshi ini sebagai bentuk 'peringan' kepada 'pengunjung' akun bahwa mereka telah memasuki area yang akan membahas mengenai homoseksual. Ini berguna agar tidak ada yang salah lapak, hingga terjadi kesalahpahaman yang berujung pada penghinaan.

Kemudian, jika kita lihat secara kasat mata, apa yang dilakukan oleh para fujoshi, yakni memproduksi, mendistribusi konten-fanfiction mengenai homoseksual-terlihat seolah mereka adalah 'kaki tangan' kelompok homoseksual. Padahal kenyataannya tidaklah demikian. Para fujoshi

\footnotetext{
${ }^{17}$ Ammar, "Eksistensi Fujoshi”, 100.
} 
memproduksi dan mendistribusikan teks hanya bentuk dari keinginan mereka terhadap suatu hal tetapi logika menyatakan hal tersebut tidaklah mungkin terjadi. Sebagai contoh seorang fujoshi menyukai idola pria, baik aktor maupun penyanyi, dan tidak menginginkan atau tidak suka idola pria tersebut dengan idola wanita lain. Mereka lebih rela idola pria tersebut bersama dengan laki-laki lain. Bagi mereka (fujoshi) ini lebih pantas dan masuk akal.

Pemikiran para fujoshi ini terkesan aneh, tidak masuk akal, dan memaksakan suatu hal. Ketika seseorang mencoba untuk bergabung dengan para fujoshi dan mendapatkan pemahaman mengenai hal demikian tentu merasa hal tersebut tidaklah sesuai. Akan tetapi, ketika seseorang yang masuk ke dalam komunitas tersebut, dan ingin menyatakan pendapatnya yang bertentangan dengan pendapat mereka, para fujoshi tersebut menolak. Bahkan orang yang memiliki pendapat berlainan tersebut secara perlahan akan terasingkan, dan tidak dipandang. Ini sesuai dengan pernyataan Newmann pada teori spiral of silence yang menyatakan: bahwa pendapat atau pandangan dominan lebih berpengaruh dibandingkan dengan pendapat atau pandangan minoritas.

Pemikiran-pemikiran fujoshi yang menghasilakan pandangan atau pendapat dominan dalam kelompok tersebut juga berlaku terhadap fujoshi yang berada di media sosial Wattpad. Sehingga pandangan tersebut mengahsilkan suatu pola unik yang selalu dan terus digunakan oleh fujoshi. Pola tersebut dapat dilihat dari produksi teks, distribusi teks, dan konsumsi teks yang fujoshi lakukan.
Fujoshi memrpoduksi karyanya (fanfiction) hanya untuk penyalur daya khayal. Meski tidak dapat dipungkiri bahwa fujoshi secara tidak langsung turut menyebarkan atau mengkampanyekan mengenai kelompok homoseksual. Terlebih dengan penggambaran cerita yang menarik, hingga mengangkat isu-isu sosial mengenai homoseksual. Penggambaran yang dibuat seolah 'cinta' yang dialami kelompok homoseksual bukan suatu hal yang salah. Dengan dibumbui isu-isu yang lazim dialami oleh kelompok homoseksual, dapat membuat pengkonsumsi bacaan ini dapat menerima kelompok gay.

Kemudian dengan menggunakan idola-idola digandrungi saat ini. Idola yang biasanya digunakan adalah idola asal Korea Selatan. Alasan mereka memproduksi fanfiction dengan menggunakan idola asal Korea Selatan selain karena menyukai idola tersebut, Idola asal Korea Selatan ini dianggap mencukupi standar ketampanan yang diinginkan. Standar ketampanan berupa tubuh tinggi tegap, dengan badan atletis serta kulit putih. Jika dahulu pria dengan kulit putih dianggap sebagai 'anak mami' yang tidak memiliki sisi jantan. Namun, saat ini penilai demikian telah bergeser dan berubah.

Alasan lainnya yang membuat mereka memproduksi fanfiction dengan menggunakan idola Korea Selatan adalah adanya sosok pria berwajah manis, imut, dan cantik. Terlebih jika kedua penggambaran tersebut berada dalam satu grup tertentu yang memang keduanya telah lazim dipasangkan. Ini dianggap sebagai paket lengkap oleh para pembuat fanfiction 
dalam memproduksi fanfiction. Paket lengkap yang dimaksud bukan hanya karena adanya pasangan tampan dan manis, melainkan karena lebih mempermudah mereka dalam melihat fanservice yang dianggap sebagai asupan untuk meningkatkan daya khayal dalam membuat fanfiction.

Meski tidak semua fujoshi menggunakan idola yang berasal dari satu grup, karena ada beberapa diantara mereka yang menggunakan idola berupa kartun seperti Sasuke dan Naruto, hingga pasangan yang dibuat berdasarkan imajinasi semata tanpa adanya visualisasi dari suatu tokoh. Selain itu, saat ini tidak hanya idola Korea Selatan saja yang digunakan sebagai visual dalam fanfiction. Ini diakibatkan dengan adanya web series asal Thailand dan China yang langsung bertemakan homoseksual. Semakin menarik dengan adanya konsep-konsep yang dibentuk sedemikian rupa oleh para penulis. Seperti, konsep seme, digambarkan sebagai sosok tampan, bersikap dingin namun perhatian, kaya, bertubuh tegap dan atletis, serta penyayang. Serta divisualisasikan dengan sosok idola yang sesuai semakin mempermudah dalam pembuatan fanfiction. Selain itu, konsep lain yang digunakan ialah uke, dimana kebanyakan fujoshi akan menggambarkan uke sebagai sosok laki-laki yang manis lembut, berkulit putih halus, dengan perawakan mungil. Terlebih jika sosok uke tersebut dapat memberikan keturunan. Ini dikenal dengan konsep M-Preg (Male Pregnant) atau lakilaki yang dapat hamil.

Istilah-istilah demikian digunakan oleh fujoshi, terlebih jika ia merupakan fujoshi garis keras dan akun, sebagai bentuk 'kode'. Dimana biasanya beberapa fujoshi terkadang tidak melihat tempat atau situasi untuk membahas mengenai couple/pasangan yang mereka favoritkan. Pembahasan ini untuk sekedar menjadi bahan perbincangan atau mendapatkan masukan dari sesama fujoshi mengenai tulisan yang akan dibuat. Istilah ini digunakan untuk menyamarkan apa yang sedang dibahas agar tidak diketahui orang lain. Teks tersebut didistribusikan dengan memberikan simbol-simbol yang dapat dipahami pembaca bahwa mereka telah memasuki area berkonten homoseksual. Tanda tersebut dapat dilihat pada bagian cover yang sebelumnya telah dibuat. Selain itu penulis fanfiction juga memberikan tanda bahwa fanfiction yang disebarkan merupakan konten homoseksual pada bagian sinopsis.

Untuk memperkuat mengenai simbol tersebut, penulis fanfiction tidak hanya meletakkan simbol pada sinopsis tetapi juga pada tagar. Tagar ini turut mempermudah bagi pembaca untuk mencari cerita serupa dengan yang mereka baca saat ini. Selain itu Wattpaders juga dapat mengetahui jumlah keseluruhan bacaan serupa yang terdapat pada Wattpad. Selain itu, peneliti juga menemukan bahwa 7 dari 20 orang menyatakan bahwa Wattpad bukan satu-satunya tempat bagi penulis fanfiction untuk menyalurkan fanfiction yang telah dibuatnya. Ini karena adanya situs web lain yang juga menyediakan tempat tersebut, meski pada dasarnya situs-situs tersebut tidak hanya mendasarkan pada konten homoseksual saja. Contoh lain dari situs web yang juga memiliki muatan terkait fanfiction 
homoseksual adalah Fanfiction.net, AsianFanfiction, serta blog pribadi seperti Wordpress.

Pembaca yang mulanya hanya membaca fanfiction dengan tema homoseksual ini sesuai dengan pasangan favorit, akan semakin berkembang. Maksudnya adalah mereka akan mulai menjamah kepasangan lainnya, atau bahkan pasangan yang tidak sesuai dengan yang biasa. Seperti, jika biasanya pasangan dalam fanfic merupakan idola dalam satu grup, namun sekarang dapat berupa idola berbeda grup hingga berbeda negara.

\section{Kesimpulan}

Berdasarkan hasil pembahasan di atas dapat peneliti simpulkan bahwa, pola konsep homoseksual yang dapat ditemukan di Wattpad tergolong unik, yaitu adanya simbol-simbol berupa gambar dan kata-kata tentang konten homoseksual. Ada kata yang menggantikan kata 'homoseksual' di Wattpad yaitu yaoi, BL, boyslove. Istilah seme dan uke, sebagai bentuk deskripsi posisi dominan dan dominan dalam hubungan homoseksual. Penulis fanfiction dalam memproduksi fanfic (teks) tidak setiap hari, tetapi ketika mendapatkan asupan berupa fanservice dari pasangan idola favoritnya.

Konten homoseksual yang diproduksi, didistribusikan, dan dikonsumsi berdasarkan pasangan idola favorit. Ada situs lain selain Wattpad yang digunakan sebagai wadah penyebaran konten homoseksual. Setelah teks dibagikan, penulis fanfiction akan membuat notifikasi melalui notifikasi notifikasi, meskipun pembaca tidak langsung membacanya saat notifikasi datang. Bahwa seseorang mengkonsumsi konten homoseksual untuk pertama kalinya melalui teman (dunia maya dan miliknya, pencarian internet, atau karena mereka KPopers). Hukum siber yang mengkhawatirkan penyimpangan seperti LGBT harus diperhatikan karena minimnya penegakan hukum di media sosial. Perlu pembahasan lebih lanjut mengenai legalitas konten (apa yang boleh dan tidak boleh) di media sosial.

\section{Daftar Pustaka}

Ammar, Izmi Wardah. "Eksistensi Fujoshi Di Kalangan Penciptaan Kebudayaan Jepang (Studi Etnografi Terhadap Wanita Penyuka Fiksi Homoseksual Di Kota Medan." Skripsi, Fakultas Ilmu Sosial dan Ilmu Politik Universitas Sumatera Utara, 2018.

Ani, Yueni Andri. "Fujoshi Ala Indonesia Dalam Penciptaan Komik." Invensi 3, no. 1 (Juni 2018): 23-32. file:///C:/Users/User/Downloads/210 4-3664-1-SM.pdf

Azizah, Husnun. "Konten Kreatif Youtube Sebagai Sumber Penghasilan Ditinjau Dari Etika Bisnis Islam (Studi Kasus Youtuber Kota Metro)." Skripsi, Fakultas Ekonomi dan Bisnis Islam IAIN Metro, 2020.

Badan Pusat Statistik. "Penduduk Menurut Wilayah dan Agama Yang Dianut." Diakses 19 Agustus, 2020. https://sp2010.bps.go.id/index.php/s ite/tabel?tid=321

Lestari, Gesti. "Fenomena Homoseksual Di Kota Yogyakarta." Skripsi, Fakultas Ilmu Sosial Universitas Negeri Yogyakarta, 2012.

Mardiani, Dwinita . Pemaknaan Media Sosial Bagi Kaum Homoseksual: Studi Fenomenologi pada Pengguna 
Grindr.” Skripsi, Fakultas Ilmu

Komunikasi Universitas Multimedia

Nusantara Tangerang Banten, 2017.

McLelland, Mark J. 'The Love Between

'Beautiful Boys' in Japanese

Women's Comic." Journal of

Gender Studies 9, no. 1 (August

2010): 13-25.

https://doi.org/10.1080/0958923001 02425

Nugrahani, Nicky Franida. "Bahaya Komunitas Homoseksual Di Media Sosial (Studi Kasus: Interaksi Virtual Community Media Sosial Gindr)." Skripsi, Fakultas Ilmu Dakwah dan Ilmu Komunikasi Universitas Islam Negeri Syarif Hidayatullah, 2016.

Prasetyo, Dana Dwi, dan Amsal Amri. "Peranan UP3AI Unsyiah mengantisipasi pengaruh pemberitaan LGBT di media online terhadap mahasiswa." Jurnal Ilmiah Mahasiswa FISIP Unsyiah 2, no. 3 (Agustus 2017): 1-12 http://www.jim.unsyiah.ac.id/FISIP/ article/view/3668

Puntoadi, Danis Menciptakan Penjualan Via Social Media. Jakarta: Elex Media Komputindo, 2011.

Putri, Rizka Ramadhani . "Penerimaan Gay Dalam Keluarga (Studi tentang Penerimaan Keluarga terhadap Anggota Keluarga yang Gay)." Skripsi, Fakultas Ilmu Sosial dan Ilmu Politik Universitas Airlangga, 2014.

Ramiyanto. "Bukti Elektronik Sebagai Alat Bukti Yang Sah Dalam Hukum Acara Pidana." Jurnal Hukum dan Peradilan 6, no. 3 (November 2017): 463-486.

DOI: http://dx.doi.org/10.25216/jhp. 6.3.2017.463-484

Santoso, Meilanny Budiarti. "LGBT Dalam Perspektif Hak Asasi Manusia." SHARE: Social Work
Jurnal 6, no. 2 (Desember 2016): 220-229

DOI: https://doi.org/10.24198/share. v6i2.13206

Uyun, Zafirah Quroatun. "Representasi Identitas Online-Offline dan Budaya Siber di Lingkungan Akademik." Serambi Akademica 8, no. 1 (Februari 2020): 61-69. DOI: https://doi.org/10.32672/jsa.v8 i1.1835

Wikipedia. "Wattpad Layanan Situs Web dan Aplikasi Android." Diakses 18 Mei, 2019. https://id.m.wikipedia.org/wiki/Watt pad

Yansyah, Roby dan Rahayu. "Globalisasi Lesbian, Gay, Biseksual, dan Transgender (LGBT): Perspektif HAM dan Agama Dalam Lingkup Hukum Di Indonesia." Jurnal Law Reform 14, no.1 (March 2018): 132146.

DOI: https://doi.org/10.14710/lr.v14 i1.20242 